INTERnational JOURNAL OF MULtidisciplinaRy Research AND ANALysis

ISSN(print): 2643-9840, ISSN(online): 2643-9875

Volume 04 Issue 11 November 2021

DOI: 10.47191/ijmra/v4-i11-06, Impact Factor: 6.072

Page No.- 1537-1539

\title{
Reflection of the Social Environment in Children's Quasidiological Speech
}

\author{
Nafisa Musaeva \\ Lecturer Navoi State Pedagogical Institute Navoi, Uzbekistan
}

ABSTRACT: This article discusses about the factors of occurrence of quasi-dialogic speech in children and the reflection of the social environment in quasi-dialogic speech.

KEY WORDS: speech, dialogue, quasi-dialogue, communication, addressee, social life.

\section{INTRODUCTION}

Nowadays, situational analysis of the impact of speech on communication of participants, while developing pragmatic approaches, focuses the attention of linguists on the study of different forms of communicative communication organization and the search for solutions to related problems.

\section{THE MAIN FINDINGS AND RESULTS}

In the process of a child's communication with adults, his/her speech is formed and improved, leading to changes and improvements in various mental processes in speech communication. A.R. Luria argues that the speech activity is the basis for complex management issues that arise in a child's behavior. [A.R. Luria, 1979: 53]

Whereas the process of verbal communication occurs through the interaction of people with each other, in children's speech sometimes their own peculiar manifestations appear. In particular, in children's speech, the object of interaction may not be a person, that is, alone can form a verbal communication. In such a speaking situation, the child plays alone, in which both the authorship of the "script" and the authorship of the text created during the game are in the child himself/herself. At the same time, playing the role of the protagonists in the game, the child creates a characteristic speech of the characters he weaves, as if he is hiding behind this or that "mask". In such a speech situation, the child performs someone else's speech rather than his or her actual speech and exhibits a certain acting quality. In linguistics such type of speech is described as quasi-logical speech.

Quasi-dialogic communication can be seen as a unique way of conveying someone's speech, as the child's authorial speech in the play is similar to the speech of the images he or she creates "The personal speech experience of each person, writes M. M. Bakhtin, - is formed and developed in constant contact with the personal speech of others. To a certain extent, this experience can be described as the process of assimilating more or less other people's speech. Our speech ... is full of words with varying degrees of alienation. Although these foreign words assimilate with their own expression, expressiveness, evaluative tone, they are processed in our speech, have their own expression "[M.M. Bakhtin 1979: 269].

It seems that children's speech is formed on the basis of adult speech. The following child-specific quasi-dialogic speech is an example of this:

(Asilbek is 5 years old boy, interested in cars, his father is a driver, in his games the driver and passenger show verbal communication)

"I'm going, I'm going, I have stopped." Where are you going, how much are you going to pay? '

- To the market, 3,000 soums, - says the client.

"Hey, sit down." ("Woon" mimics the sound of a car). I will stop, I run out of gas, I will fill up, get out of the car. It is filled. Let's continue.

"Could you please, take me to the clothing market and I'll buy shoes for my son," he said.

"Here we are, get out of the car, please." 


\section{Reflection of the Social Environment in Children's Quasidiological Speech}

Children get such speech from the events around them, TV advertisements and shows, cartoons, social life. This situation can be explained by the following factors:

1) Lack of verbal communication with peers - the child is alone, he lacks communication, peers. Therefore, as an authorcreator, he/she expresses his/her impressions of social life through the speaker and listener he/she has created;

2) reluctance to communicate, shyness - the child is reluctant to share their thoughts, impressions of social life with others. So he/she plays by talking to himself/herself;

3) living in their own world - such a child has almost no friends, living in his/her own shell. It is as if he understands it only by himself/herself. This situation is also often the result of a lack of parental support;

4) the breadth and richness of the imaginary world - such children have a strong desire to look at life differently, to bring to life the images they see in cartoons, on screens;

5) lack of parental attention occurs in order to attract adults, to make them aware of their existence;

6) stressful situations- when the child is under stress, he/she will have a desire to hide himself/herself; and the child will have a desire to escape from real life;

7) family conflicts occur the desire of living in a comfortable and secure life by avoiding conflicts.

8) playful state is the normal state. In doing so, the child speaks with the realization that the interlocutors he or she has created do not really exist.

9) mental illness is the most widespread and complex diagnostic condition. It is not easy to determine if a child is thinking in a healthy way or if it is a psychopathological condition.

It appears that the occurrence of quasi-dialogic speech in children's speech depends on a variety of factors. Quasidialogic speech has characteristic features such as free, indirect speech. The speech actions of adults in social life are reworked by the child. They all operate according to a plan in the presence of a synchronous addressee. In other words, speech is clearly reworked based on the child's creative imagination. For example:

(Muharram is 6 years old girl, often goes to the beauty salon with her mother. She performs this process with her dolls during the game.)

"Good day," she said, as if entering a beauty salon.

"Good day, come in please," said the hairdresser, complimenting her like a girl.

"I came to have my hair cut and makeup done," she says.

"Please, sit down," she said politely.

"Make me as beautiful as a princess, please, there is a party in the kinder garden," she said.

"All right, ma'am, we started there," she said.

"Don't cut my hair too short, my mother will punish me, don't make my lips red, my father will punish me," she said sadly.

"Ma'am, you'll be very beautiful now," said the hairdresser, using a hair dryer, scissors, comb, and so on, to make the doll's hair look beautiful. .

"Oh, I'm so beautiful, thank you so much." Now I go to the garden party and dance. "Here's the money for you," she said, handing over the paper.

"You are welcome."

These processes are curiosities, appearances of the speaker-character, dreams, in which the decisive role is played by the text in the context. Such speech situations are based on egocentric speech that accompanies the child's actions.

In a particular replica of a quasidialog, speech is not volitional for the first time: in it, "speech echo" is common. The child imitates, accepts, or rejects "other people's words" on his or her own. Apparently, quasi-dialogic speech can be evaluated as speech, which serves to form the child's attitude to other people's speech, the ability to orient freely in different communication situations.

Hence, the participants in the dialogue of the quasi-dialogue performed by the speaker are this or that image, familiar and unfamiliar characters. In this case, the author hides behind a "mask" of a certain character, which identifies a particular type of children's text that we are analyzing. The text created by the child during the game differs from the literary text with its peculiarities:

Firstly, the text is a reflection of the communicative situation created: the replica of the speaker and the listener does not differ in time and space, as in free communication, but corresponds to one person, because "performed quasi-dialogue is a is a return speech" [Vinokur 1993]. 


\section{Reflection of the Social Environment in Children's Quasidiological Speech}

Secondly, in the artistic world to which the author refers and does not belong, the originality of the world created by the author's own imagination is reflected.

Our observations show that during the game, the child creates a quasi-dialogic speech based on the expression of the processes that occur during his social life.

\section{CONCLUSION}

So, in the quasi-dialogue performed by children in the process of play, the following can be shown about the speech features of the speaker.

1. The absence of the addressee in the game situation reflects the managerial features of the speaker: in the process of playing on the basis of creative imagination, real unfinished communication is fully realized by the child.

2. Speech-character replicas based on the child's egocentric speech have a special place in the quasi-dialogue: they are the result of "speech interference," i.e., the intersection of the author's speech and the character's speech.

3. Since the images are presented as "masks" of the author, we can talk about a special way of conveying someone's speech: a) "foreign" speech is created and performed by the child himself; b) speech is not created, it is repeated. The identity of the author and the speaker, i.e., the 'masks', is manifested as a reflection of the people around the speaker in social life.

\section{REFERENCES}

1) Bakhtin M.M. Aesthetics of verbal creativity. - M., 1979 .-P.296

2) Vinokur T.G. Polylog // Linguistic encyclopedic dictionary. - M., 1992.-P.381.

3) Vinokur T.G. Speaker and Listener. Variants of speech behavior. - M., 1993.- P.172.

4) Voloshinov V.N. Marxism and the Philosophy of Language: The Main Problems of the Sotsiological Method in the Science of Language. - L., 1930 .-P.151.

5) Davlatova R., Musaeva N. Issues of dialogue and quasi-dialogue in linguistics. Journal of Uzbek language and literature. Tashkent - 2021. Issue 3

6) Luria A.R. Language and Consciousness. - M., 1979.-P.53.

7) Paducheva E.V. Semantic research (Semantics of time and type in Russian; Semantics of narrative). - M., 1996 .-- $464 p$.

8) Petrova T.I. Staged quasi-dialogue as a special genre of children's speech (based on the speech of children 6-8 years old). Diez. Cand. Phil. sciences. Vladivostok, 2000 .-- 168p. 